Björn Gustafsson 1,2,5*, Ludmila Nivorozhkina ${ }^{3}$ and Haiyuan Wan ${ }^{4,5}$

\title{
Working beyond the normal retirement age in urban China and urban Russia
}

\begin{abstract}
The incidence of working for earnings beyond the normal pension age of 55 for females and 60 for males in urban China and Russia is investigated using micro-data for 2002, 2013, and 2018. Estimated logit models indicate that, in both countries, the probability of working after normal retirement age is positively related to living with a spouse only, being healthy, and having a higher education level. It is negatively associated with age, the scale of pension, and, in urban China, being female.

We find that seniors in urban Russia are more likely to work for earnings than their counterparts in China. Two possible reasons that are attributable to this difference are ruled out, namely cross-country differences in health status and the age distribution among elderly people. We also demonstrate that working beyond the normal retirement age has a much stronger negative association with earnings in urban China than in urban Russia. This is consistent with the facts that the normal retirement age is strictly enforced in urban China and seniors attempting to work face intensive competition from younger migrant workers. We conclude that China can learn from Russia that it has a substantial potential for increasing employment among healthy people under 70 .
\end{abstract}

Current version:

Keywords:

JEL codes:

Corresponding author:
April 19, 2021

retirement, older people, employment, China; Russia, labor market J14; J26; J31; J7; P23

Björn Gustafsson

Bjorn.Gustafsson@socwork.gu.se

1 Department of Social Work, University of Gothenburg, SE 40530 Göteborg, Sweden

2 Institute for the Study of Labor (IZA), Bonn, Germany

3 Department of Statistics, econometrics and risk assessment, Rostov State Economic University, 344002 Rostov-on-Don, Russia

4 Business School, Beijing Normal University, Beijing, China

5 China Institute for Income Distribution, Beijing Normal University, Beijing, China

(c) The Author(s). 2021. Open Access This article is distributed under the terms of the Creative Commons Attribution 4.0 International License (http://creativecommons.org/licenses/by/4.0/), which permits unrestricted use, distribution, and reproduction in any medium, provided you give appropriate credit to the original author(s) and the source, provide a link to the Creative Commons license, and indicate if changes were made. @- (-) Cite as: Gustafsson et al. IZA Journal of Development and Migration (2021) 12:05 


\section{Introduction}

The People's Republic of China and Russia share the trait with high-income countries that their populations are becoming older. Figure 1 illustrates the consequence of low birth rates and better health status. The recent declines in labor forces have brought pressure on public expenditures on pensions, healthcare, and long-term care. One strategy to counteract the consequences of an aging population is by extending working lives. (See, for example, Maestas and Zissiopoulos (2010).) If pensions are drawn later in life, the budget restrictions on the public sector will be relaxed. Furthermore, if people remain in the workforce longer, GDP will increase and the resulting higher tax revenues can be used to fund public programmes. This is the main motivation underlying our efforts in endeavoring to find out the reasons for older people in urban Russia and urban China to work after the normal retirement age and to explain why such situation is more common in urban Russia.

An intuitive reason to compare working after the normal retirement age in urban China and Russia is the similar origin of their economic and social insurance systems. The socialist economy in the two populous countries has influenced their labor markets and pension systems. Specifically, from 2002 to 2018, both countries had the same normal retirement age for workers, that is, 55 years for women and 60 years for men. Furthermore, China and Russia are

Figure 1 (A) Proportion of population aged $65^{+}$. (B) Proportion of population aged 15-64.

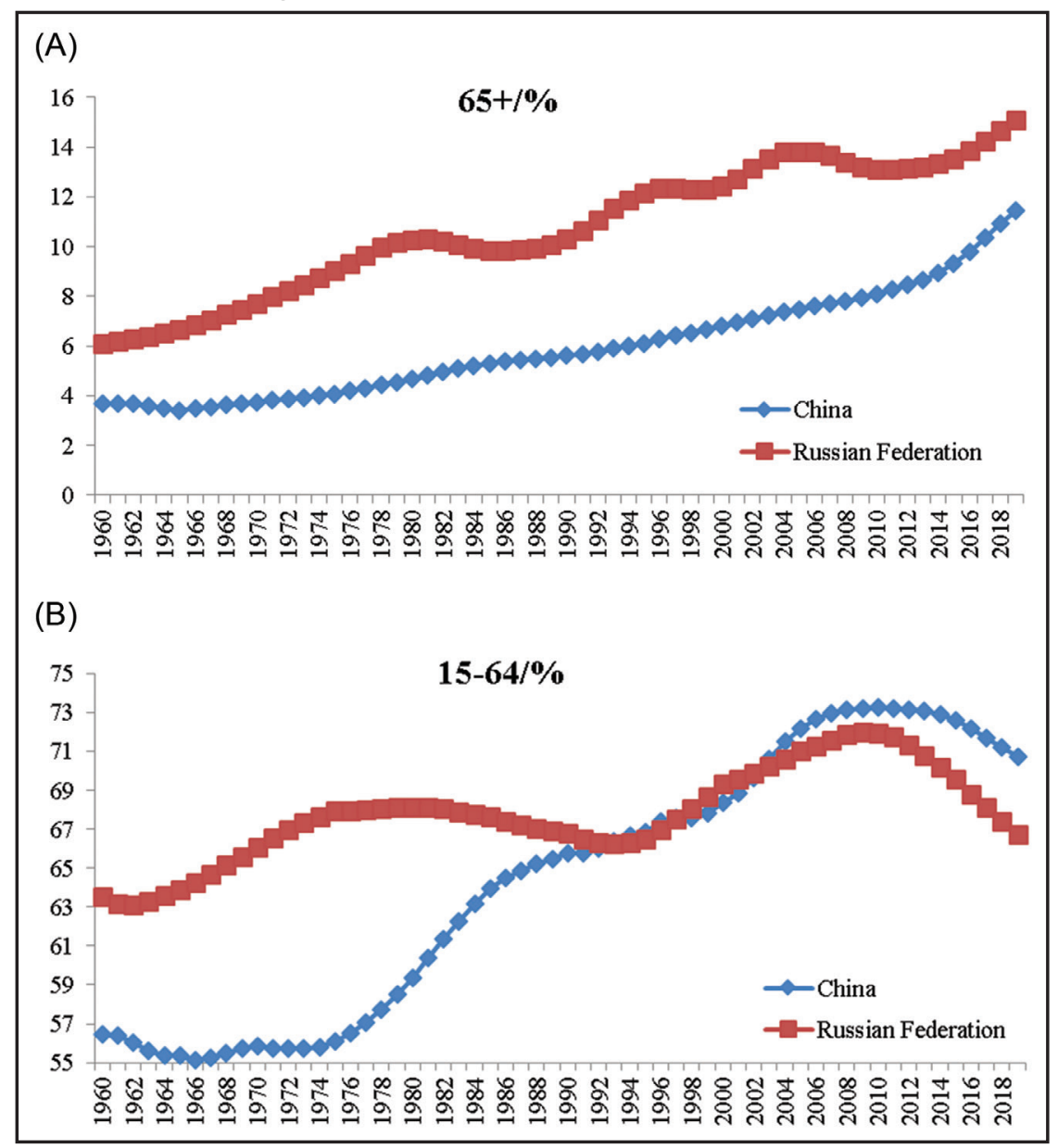

Source: International Labour Organization, ILOSTAT database. (https:/ data.worldbank.org/indicator/SP.POP.1564.TO.ZS) 
currently classified as middle-income countries. The first task for this article is to document the similarities and differences in the proportions of the population who work for earnings after normal retirement age in urban China and urban Russia. We demonstrate that these differences are significant because it is considerably more common for people over the normal retirement age in urban Russia to work for pay than their counterparts in urban China.

Our second task aims to find out why such significant cross-country differences exist in the proportion of older people who work after the normal retirement age. Reasons can consist of cross-country differences in the composition of the older population, as well as societal differences. We report that there is no empirical support for explaining the larger proportion of urban senior workers in Russia from the differences in population composition.

At the societal level, many possible reasons could explain why a larger proportion of people who have reached the normal retirement age work for earnings in urban Russia as compared with urban China. For example, the different macroeconomic experiences over recent decades might have affected the economic expectations in the two countries. In the past, the Chinese economy had high rates of economic growth, whereas Russia experienced huge negative economic growth rates during the 1990s after the collapse of Soviet Union and the planned economic system. Another difference between urban China and urban Russia, probably relevant for the number of post-retirement age workers, is the differences in norms related to family arrangements.

In the following sections, we argue that differences in the labor market are the primary social difference that affects the number of post-retirement age workers in urban China and urban Russia. The picture we present is that older Chinese urbanites who attempt to work beyond the normal retirement age meet competition from young migrant workers, whereas this is much less the case in urban Russia. Furthermore, the normal retirement age is more strictly enforced in urban China than in urban Russia. We provide support for these arguments by presenting estimated wage functions, which indicate that among wage earners, earnings are much more strongly negatively related to age in urban China than in urban Russia.

This article is organized as follows. In the next section, we describe some distinct differences between urban China and urban Russia and their evolutions. Section 3 contains a short review of the literature with a detailed Appendix. Possible reasons for working after the normal retirement age are discussed in Section 4, before we describe the data in Section 5, where we also characterize seniors who work. Section 6 reports employment rates for the samples as well as the estimated employment functions. In Section 7, we focus on earnings among workers aged below and above the normal retirement age. Finally, we summarize and conclude our study in Section 8.

\section{Context}

After introducing the Soviet economic system in the 1950s, most firms in urban China became state owned or collective owned, and the private sector shrank to become very small. As in the Soviet Union, almost all females and males of working age were employed until they reached the normal retirement age, which was set, with some exceptions, at 55 years for female workers and 60 years for male workers. Urban workers had access to heavily subsidized housing, health and social services, pension rights, and a meager wage. Labor mobility was very low and most 
urban Chinese workers look forward to pensions. Inspired by the Russian propiska (registration system), China introduced its hukou system, which effectively separated the privileged urban minority from the disadvantaged rural majority.

In most respects, however, this description of urban China and urban Russia has been obsolete for several years. In the beginning of the 1990s, the Soviet Union underwent substantial political changes. The entity fell apart and the Communist Party lost its leading role. The 1990s also witnessed a period of economic turmoil in Russia. Persistent high inflation decreased the real value of bank savings. There was mass privatization, very rapid decreases in GDP (see Figure 2), and real earnings fell dramatically (for details, see, for example, the various contributions in Alexeev and Weber (2013)). For some years, far from all workers and pensioners did not receive their incomes on time. Life expectancy fell sharply (see Figure 3), and open unemployment appeared at the end of the millennium. In such an environment, Russian pensioners had to find ways to cope with their economic problems (see, for example, Tecernina and Techernin (2002)). Many people had to work to earn a living even after reaching the normal retirement age. Since the Russian Pension fund began to face large funding

Figure 2 GDP per capita in China and Russia in constant Purchasing Power Parity (PPP).

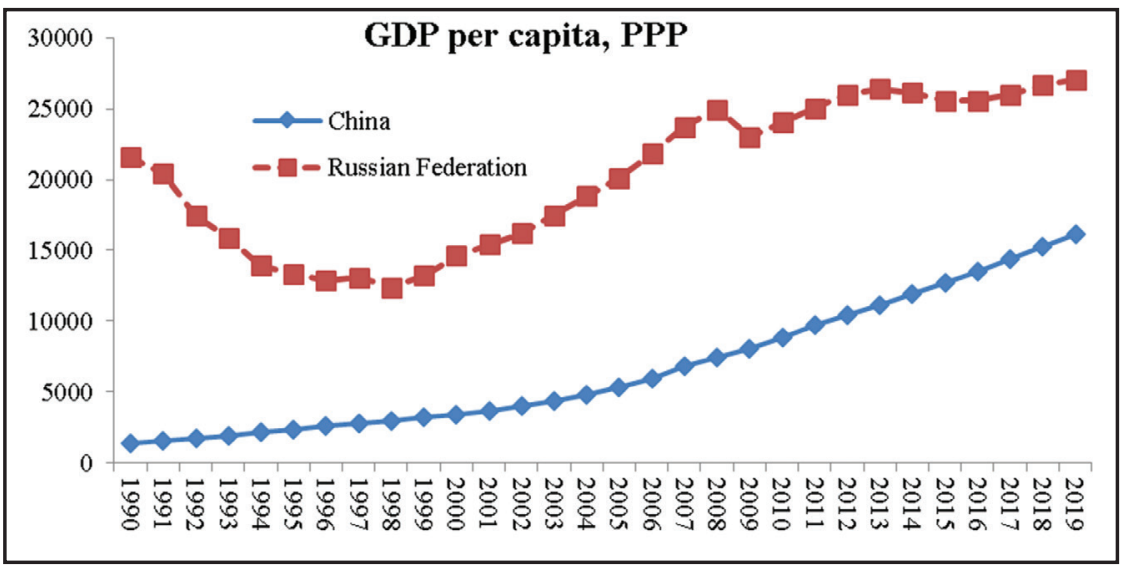

Note: GDP per capita and Purchasing Power Parity (PPP) are expressed in constant 2017 international dollars.

Source: World Bank, International Comparison Program database. (http:// data.worldbank.org/indicator/NY.GDP.PCAP.PP.KD)

Figure 3 Life expectancy at birth in China and Russia, 1975-2018.

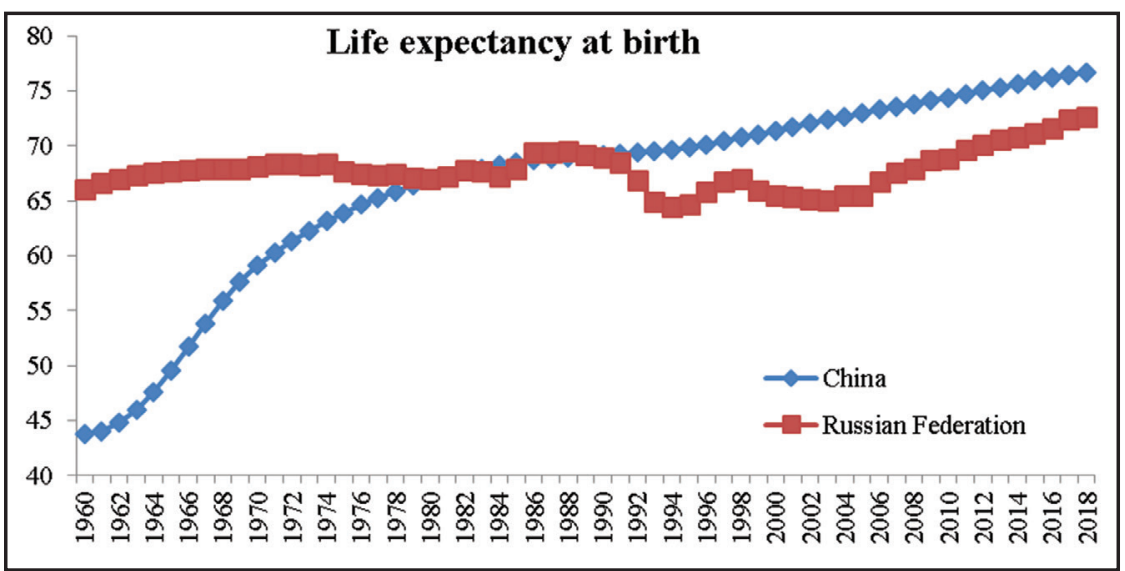

Source: World Bank, International Comparison Program database. (http:// data.worldbank.org/indicator/SP.DYN.LE00.IN?) 
problems, in September 2018, the Russian Parliament passed a law to increase the normal pension age starting in 2019 so it will become 60 for females and 65 for males in 2023 (see Brandt (2018)).

In contrast to Russia's situation, the political system in China has now been intact for several decades. Real household income grew from a relatively low level and continued to rise. Life expectancy used to be lower, however, has increased to a higher level compared with Russia (see Figure 3). Unlike in Russia, most economic reforms in China were gradually introduced (see, for example, Naughton (2018)). Reforms started in rural regions at the end of the 1970s and were then extended to urban regions. Privatization in China also proceeded slowly. It was not until the end of the 1990s that private sectors started to develop in urban China. State-owned enterprises were put under market pressure, and lifetime employment relationships between workers and their employers were abolished. Consequently, many workers were laid off and several became unemployed.

While the experiences of the 1990s were rather different in urban China than in urban Russia, with regard to macroeconomic development, the divergence since then has not been as dramatic. The increase in the price of oil and other natural resources stimulated the Russian economy to grow during the first years of the new millennium (see Figure 2). Simultaneously, life expectancy increased, as was the case in China (see Figure 3). Following the slowdown of the global economy in 2008, the Russian GDP decreased by $8 \%$ in 2009, but it caught up in the years that followed, and growth continued until 2013, after which there was a slightly downward trend. In contrast to most countries, China continued to experience high GDP growth rates during the Great Recession, although the rates became less impressive when compared with previous years.

The different macroeconomic experiences in China and Russia indicate that most elderly people living in urban regions in 2002, 2013, and 2018, the three years we investigate, have had rather different economic experiences before reaching the normal retirement age. Most of older Chinese residents have received rapidly increasing incomes, but this was not the case among older Russian people. Furthermore, in contrast to Russia, China has rapidly urbanized, due to a large inflow of migrants from rural areas during the years we investigate. Consequently, the labor market for older people in urban China has developed differently from the labor market for older people in Russia, an issue to which we will return in Section 7.

\section{Literature Review}

Several empirical studies focus on why people work beyond the normal retirement age in high-income countries. A pattern of factors of importance is emerging, which indicates that participation in the labor market during old age is the outcome of complex interactions among health/disability, family, and caring responsibilities, as well as the financial resources of the person and household (Komp et al., 2010; Wahrendorf et al., 2017; Nolan and Barrett, 2019; Anxo et al., 2019). In contrast, the importance of post-retirement jobs conditions remains largely unexplored (Dingmans and Henkens, 2020).

In the Appendix, we review previous studies on working after reaching the normal retirement age in urban China and urban Russia. We conclude that two factors stand out in both countries, ill health and old age, which are negatively related to the activity work after the 
normal retirement age. In both countries, older females have somewhat lower rates of participation in the labor market when compared with men. In some studies, employment after the normal retirement age is positively related to education levels, which in turn might be an indicator of job conditions. Another insight from the literature is that unlike hired workers, who are often separated from work when they reach the normal retirement age, such a mechanism does not exist with respect to self-employed workers. We also conclude that while the Russian data we work with have been used for several studies on working after the normal retirement age, this has not been the case for the Chinese data used in this study.

The proportion of people working after the normal retirement age differs widely across high- and middle-income countries. For example, among EU countries, the proportions of workers at the age of 65 to 75 in 2019 were 2\% in Spain, 3\% in Belgium and France, 11\% in Ireland and the United Kingdom, 12\% in Portugal, and 14\% in Estonia (Eurostat, 2019). This variation supports the claim that societal circumstances are important determinants of the proportion of post-retirement age workers. However, research has only begun to address why it is more likely for people in some high-income countries to work beyond the normal retirement age than in others. One contribution is Dingemans et al. (2017), who, using data from the Survey of Health, Ageing and Retirement in Europe (SHARE) report that among EU countries, high expenditures on pensions lower the likelihood of older people working beyond the normal retirement age. Furthermore, norms that support working beyond retirement age are positively associated with a higher probability of the older person working for earnings.

\section{Reasons for a Larger Proportion of Older Adults Working for Earnings in Urban Russia than in Urban China}

This section discusses the means by which we can understand the finding that a larger proportion of people beyond the normal retirement age in urban Russia work for earnings when compared with their urban China counterparts. Let us take as a point of departure the individual's choice between leisure and work, as modeled in a one-period framework. Looking at a given population, older persons have various choice sets and preferences, which will result in variation pertaining to the question of whether they work after the normal retirement age. The different choice sets result from health, which is quite intuitive and consistent with the literature. Specifically, healthy persons are more likely to work after the normal retirement age than those who are not healthy. Those who have just passed the normal retirement age tend to have more access to job opportunities than those of greater ages. In addition, the decision to work is linked to alternative ways to earn a living: if the seniors receive a relatively large pension, large transfers from the public sector, or a high income from capital, and has the opportunity to sell assets, he or she can afford not to work.

Here we present some comments on the role played by pensions and income from capital in urban China and urban Russia. Starting with income from capital, it is well known that in many Western countries, a considerable proportion of seniors receive some capital income and can also afford to reduce their capital assets. However, private property has a much shorter history in today's China and Russia. Therefore, in the two countries we investigate, such sources 
are most likely unimportant for most seniors' decisions about whether to work after the normal retirement age. ${ }^{1}$

In terms of old-age pensions, the fact is that both countries provide pensions to urban workers during their economic planning period. Before reaching the normal retirement age, many urban adults have experienced long periods of working for earnings. Consequently, a large proportion of the seniors we surveyed in 2002, 2013, and 2018 were entitled to receive pensions. There were no requirements for individuals to refrain from work when receiving a pension. However, in each country, the size of the pension differed substantially among recipients. Relatively large pensions were received by people with a long working career who had had well-paid jobs. Seniors with interrupted work histories (for example, due to lay-offs), those who had worked some years in privately owned firms that did not fully or at all comply with requirements to make contributions to social insurance, and those who had worked in less qualified jobs, or worked part-time, received smaller pensions. ${ }^{2}$ We move on to discuss the kind of difference that exists between urban China and urban Russia in relation to the size of the pension received after retirement, i.e., the degree of pension adequacy. Calculations based on the data for 2018, which we describe in the next section, indicate no large cross-country difference in the average replacement rate as it is estimated at $53 \%$ for both men and women in urban Russia, 64\% for males in urban China, and 66\% for females in urban China.

From the preceding discussion, we conclude that several individual factors are supposed to negatively affect the probability of a senior working in a given country, including ill health, old age, and large pensions. It is possible to apply such factors when comparing the proportion and determinants of seniors choosing to work in urban China and in urban Russia. As measured by life expectancy, elderly Chinese people in 2002, 2013, and 2018 were healthier than their Russian counterparts (see Figure 3). Subjective assessments also indicate that elderly Chinese people have lower levels of depression than their Russian counterparts. ${ }^{3}$ Furthermore, as we will demonstrate, the urban Chinese population aged 55/60 to 75 are generally younger than their Russian counterparts. Based on these differences, one would expect seniors in urban China to work for earnings to a greater extent than their counterparts in urban Russia. However, Russian seniors have a higher average level of education than Chinese seniors. As we will demonstrate, there are indications that seniors with a higher level of education have a higher probability of working than those with a lower education level.

Although the theoretical framework discussed above indicates that several factors can affect the choice to work beyond the normal retirement age, the framework has several limitations when applied to the cross-country comparison. One is that the choice to work is often not completely made by the individual but influenced by his or her family. Since cultural values also influence public policy, it is safe to state that family plays a different role in urban China than in urban Russia. For example, older people's previous investments in human capital in

1 According to the National Bureau of Statistics (NBS) (2014), property income made up only $1.3 \%$ of total income in urban China in 2002, which increased to $2.7 \%$ in 2013. The corresponding proportions in Russia were larger at $5.2 \%$ in 2002 and 5.5\% in 2013; see Federal State Statistic Service - Rosstat (2018).

$2 \mathrm{Wu}$ (2013) and Liu and Li (2016) provide more details on the Chinese pension system, and Kovrova (2007) on the Russian pension system.

3 This is reported by Hsieh (2015) who analyzed the data from the first wave (2007-2010) of the World Health Organization Study on Global Ageing and Adult Health. This study gives support for the view that a higher economic security level and a greater degree of social cohesion among the Chinese respondents are imperative in understanding cross-country differences in health status. In contrast, the same study found no support for cross-country differences in health rating styles in functioning as an important factor with which to explain cross-country differences in health. 
their offspring can lead parents to expect some rewards from their children later in life, such as cash transfers, personal services, or cost reductions through sharing of housing. ${ }^{4}$ We notice in our data that co-habitation with other adults (including adult children) is considerably more prevalent in urban China than in urban Russia (see Table 1). It is possible that the option of living with younger generations is not available or is not as attractive for seniors in urban Russia as it is for seniors in urban China. Consequently, this possibility accounts for the fact that a larger proportion of seniors in urban Russia work for wages, as compared to urban China. The care of children also matters in many Chinese families. For example, a member of the oldest generation plays a vital role in his or her grandchild's life. To take such a role seriously, some grandparents (especially grandmothers) might quit working. In the past years, the Chinese policy system has not paid much attention to public childcare for children below 7; thus, grandparents' caring has traditionally been a key component of family support in China. ${ }^{5}$

In addition to cross-country differences in macroeconomic experiences, pension systems, and the role of the family, there are also cross-country differences in the labor market that are significant for determining the number of post-retirement age workers and their characteristics. For example, Feng et al. (2020) state that in urban China, reaching the retirement age means that one must go through the retirement process, retire from one's current job, and start receiving public pensions. After that, an individual can stay in the labor market informally without losing the pension benefit, but the opportunity to find a job declines drastically. A clear majority of employees comply with the retirement-age policy and retire institutionally at the mandatory retirement age. Data from the CHARLS, a nationally representative sample of Chinese residents aged $\geq 45$ years, indicates a jump in the transition to retirement for men at 60 and women at 50 in urban areas.

Unlike in China, an employee in Russia can continue to work at his workplace or move to another job. On reaching the retirement age, official employment opportunities do not become limited. ${ }^{6}$ Restrictions exist only for persons working in the public service. They must leave their workplace when they reach 65 , which is above the normal retirement age. Thus, we conclude that workers are under more pressure to leave working life when they reach the normal retirement age in urban China when compared with their counterparts in urban Russia.

Furthermore, the Chinese urban labor market is considered to be more segmented than its Russian counterpart. The secondary labor market in urban China, with lower compensation and more impoverished working conditions compared to the primary market, is filled mainly by migrants with a rural hukou. Discrimination based on hukou status when hiring a worker is very common in urban China (Alexander and Chan, 2004; Wu and Treiman, 2004). Furthermore, to guarantee a high urban employment rate, some urban governments use administrative measures to restrict farmers' migration to cities or well-paid industries and positions. In addition, the policy makes it difficult for people with rural hukou to acquire legal rights to live in an urban area, which stimulates discrimination in employment and social

4 Several authors have investigated the degree and the circumstances when older people in urban China are supported by their adult children. Such studies include Lee and Xiao (1998), Cai et al. (2006), and LaFave (2016).

5 Please refer to Du et al. (2019), who used the China Health and Retirement Longitudinal Study (CHARLS) (1991-2011) and reported that the use of grandparent-provided childcare was much more common in urban China than the use of daycare programs (48\% versus 23\%). For Russia, Arnstein et al. (2012) report that, according to Generation and Gender Survey 2004, one-fourths of mothers with children aged between 0 and 14 are looked after by grandparents.

6 See Gerber and Radl (2014). 
security. The retirees with urban hukou often compete with these migrants in low-paid positions. ${ }^{7}$ Such competition would seldom occur for older persons in urban Russia because present-day Russia is much more urbanized than China and does not have a large pool of potential migrants with low education backgrounds.

To summarize, we conclude that there are both theoretical and empirical reasons to expect that in a given situation, a number of individual factors are related to the probability of working after the normal retirement age for seniors. In applying these factors to differences in the proportion of seniors who work after reaching the normal retirement age across urban China and urban Russia, health and age suggest that a larger fraction of urban elderly people should be working after the normal retirement age in China than in Russia, whereas the higher education level of Russian seniors points in the opposite direction. However, when making comparisons across countries, several societal circumstances should be considered, such as macroeconomic experiences, the role of pensions, the role of family, and (as we will further develop in Section 7) the situation in the labor market.

\section{Data and Characteristics of Seniors}

The Chinese data used in the current study are from the China Household Income Project (CHIP) and are the outcome of collaborations between the researchers who designed the questionnaires and the NBS, which was responsible for sampling and fieldwork. In this article, the three cross-sectional surveys about people with urban residence permits in 2002, 2013, and 2018 are similar in many aspects. ${ }^{8}$ The nationally representative samples were obtained through a multistage procedure in which the province-level units, Beijing, Shanxi, Liaoning, Jiangsu, Anhui, Henan, Hubei, Guangdong, Chongqing, Sichuan, and Gansu, were obtained from larger samples that are regularly used by the NBS to produce official statistics for China. ${ }^{9}$ The samples include households and individuals living in cities of various sizes. For further details, see for example, Gustafsson et al. (2014).

For Russia, we work with the 2002, 2013, and 2018 cross-sections of the Russian Longitudinal Monitoring Survey (RLMS), a series of nationally representative surveys that are designed to examine the effects of Russian reforms on the health and economic welfare of households and individuals. The ongoing longitudinal survey began in 1994 with the Phase II survey and the sample is derived through multistage probability sampling of households. Interviewers were required to visit each selected dwelling up to three times to secure the interviews. For further details on the RLMS, see for example, Kozyreva et al. (2016).

We use information from the CHIP and the RLMS on urban residents, including all females aged between 55 and 75, and males aged between 60 and $75 .{ }^{10}$ In each year, the Chinese sample is larger than the Russian sample. Table 2 indicates that the smallest sample (the RLMS

7 Zhang and $\mathrm{Wu}$ (2017) provide evidence that the earnings' disadvantage of urban migrants compared with urban residents is largely attributable to occupational segregation (between-occupation variation) by the workers' household registration status (hukou), rather than to unequal pay within the same occupation. On this issue, see also Ma (2018).

8 Among the six samples we work with was the Russian sample for 2002, which was generated during a year of higher unemployment than the other five samples. World Bank (2021) reports the following unemployment rates (percent) for China/Russia: 4.2/7.9 (2002), 4.6/5.5 (2013), and 4.3/4.8 (2018).

9 For comparability reasons, we did not include provinces that were not surveyed in each of the three years.

10 The definition of "urban" used in the Chinese data is the administrative definition. Thus, we only include persons with an urban hukou and exclude migrants living in urban areas with a rural hukou. To make the Russian samples more comparable to the Chinese urban samples, we followed the definition in RLMS, which is based on practice used in official Russian statistic by removing respondents who lived in settlements with fewer than 20,000 inhabitants. 
Table 1 Older people in urban China and urban Russia in 2002, 2013, and 2018 by characteristics

\begin{tabular}{|c|c|c|c|c|c|c|c|}
\hline & & $\begin{array}{l}\text { China } \\
2002\end{array}$ & $\begin{array}{l}\text { China } \\
2013\end{array}$ & $\begin{array}{l}\text { China } \\
2018\end{array}$ & $\begin{array}{c}\text { Russia } \\
2002\end{array}$ & $\begin{array}{c}\text { Russia } \\
2013\end{array}$ & $\begin{array}{c}\text { Russia } \\
2018\end{array}$ \\
\hline \multirow[t]{2}{*}{ Gender, \% } & Female & 59.2 & 60.2 & 59.8 & 72.7 & 72.9 & 73.5 \\
\hline & Male & 40.8 & 39.8 & 40.2 & 27.3 & 27.1 & 26.5 \\
\hline \multirow[t]{3}{*}{ Living arrangements, $\%$} & Living alone & 2.6 & 2.5 & 3.9 & 23.3 & 22.7 & 27.6 \\
\hline & Couples & 28.6 & 27.4 & 25.2 & 29.9 & 30.6 & 26.8 \\
\hline & All other living arrangements & 68.8 & 70.0 & 70.9 & 46.8 & 46.7 & 45.7 \\
\hline \multirow[t]{2}{*}{ Age, $\%$} & $55 / 60-70$ & 73.2 & 69.9 & 69.1 & 58.6 & 60.1 & 60.3 \\
\hline & $70-75$ & 26.8 & 30.1 & 31.0 & 41.4 & 39.9 & 39.8 \\
\hline \multirow[t]{4}{*}{ Education, $\%$} & Low & 36.9 & 35.2 & 31.6 & 40.2 & 25.1 & 14.2 \\
\hline & Upper middle & 39.7 & 46.0 & 53.1 & 19.1 & 19.3 & 23.7 \\
\hline & Polytechnic & 17.8 & 7.5 & 4.9 & 20.1 & 31.1 & 33.2 \\
\hline & Higher & 5.6 & 11.3 & 10.5 & 20.7 & 24.6 & 28.9 \\
\hline \multirow[t]{3}{*}{ City size, $\%$} & Large & 6.7 & 15.5 & 12.1 & 58.2 & 57.6 & 50.5 \\
\hline & Middle & 30.4 & 19.4 & 32.1 & 34.0 & 33.5 & 33.1 \\
\hline & Small & 62.9 & 65.0 & 55.9 & 7.8 & 9.0 & 16.4 \\
\hline \multirow[t]{3}{*}{ Health status, $\%$} & Healthy (good and very good) & 42.3 & 44.9 & 50.3 & 5.3 & 8.0 & 6.7 \\
\hline & Not good, not bad & 40.2 & 42.9 & 37.4 & 57.4 & 59.9 & 60.7 \\
\hline & Not healthy (bad and very bad) & 17.5 & 12.2 & 12.3 & 37.4 & 32.1 & 32.3 \\
\hline \multirow[t]{2}{*}{ Pensions } & Percentage with a pension, $\%$ & 74.6 & 87.3 & 97.3 & 99.5 & 96.6 & 99.0 \\
\hline & $\begin{array}{l}\text { Ln pension (in local currency, } \\
\text { and } 2013 \text { prices), mean value }\end{array}$ & 9.3 & 9.7 & 9.7 & 8.5 & 9.3 & 11.8 \\
\hline \multicolumn{2}{|c|}{ Number of elderly respondents } & 2424 & 3404 & 6885 & 1591 & 3233 & 3240 \\
\hline
\end{tabular}

Note: The table refers to women $>55$ years old and men $>60$ years old, both being at most 75 years old.

Source: Authors' calculations from the CHIP and the RLMS data.

2002) has 1,591 observations and the largest (the CHIP 2018) has 6,885 observations. Table 1 provides basic characteristics of the six samples.

Females are more numerous in the samples for both countries and to a greater extent in the Russian samples. This should be seen from the background of lower normal retirement age for females (55 compared to 60 for males) and the substantial cross-gender gap in life expectancy in Russia. According to data from the World Bank in 2018, the gender gap in life expectancy in Russia was 10 years, while it was not more than 4 years in China. This is because the life expectancies for females were rather similar in China (79 years) and in Russia (78 years); however, life expectancies for males in China and Russian were 75 years and 68 years, respectively (see World Bank, 2020). It should be understood that statistics on life expectancy are a construct based on recent observations of age-specific mortality rates. We report a considerably higher employment rate of the elderly in urban Russia than in urban China, even though Russia's life expectancies for males are shorter.

From Table 1, we can also see that among elderly Russians, a larger proportion have higher education levels than their Chinese counterparts. According to their self-assessments, Russian seniors are also less healthy than elderly Chinese people. ${ }^{11}$ There are substantial differences in living arrangements between the elderly people in the two countries. The proportion of seniors

11 This is consistent with the findings of Hsieh (2015) (see note number 3). 
in urban Russia living completely alone is considerably higher than that in urban China, where it is very low. Most elderly Chinese people live in a household with a non-elderly person, whereas just under half of elderly Russian people are in such circumstance. In the three surveys in urban Russia, almost all households with an older member reported that they had received a pension. The situation is different in urban China, particularly in 2002, when pension arrears were common (See Hurst and O’Brian, 2002).

\section{Employment Rates and Employment Probabilities}

We define "being employed" in the Chinese data as having answered the following question affirmatively: "Did you work during the preceding year?" According to the survey manual, persons worked for at least one month were classified as working. In the Russian dataset, we required the respondent to indicate that he or she was currently employed, or answer that he or she was currently employed in a primary job or that he or she had done additional work in the last 30 days for which the respondent has been paid or will be paid. In addition, a respondent was classified as working if he or she worked in an extra job or provided services for pay in the last 12 months.

In Table 2, we report employment rates computed for the three years under study for all seniors and for some subcategories of seniors in both countries. ${ }^{12}$ A considerably larger proportion of the urban Russian seniors worked for pay than their counterparts in urban China. In urban China, the proportion of seniors working climbed from 5\% in 2002 to $11 \%$ in 2013, and became 12\% in 2018. Likewise, the similar increasing trend also occurred in urban Russia during the same period, and the ratios were 17\%, 23\%, and 26\% in 2002, 2013, and 2018, respectively. ${ }^{13}$ This increase in the proportion working for earnings is consistent with the longer life expectancies and according to Table 1, across the years, people in both countries became healthier, and the fraction of the population with a higher level of education increased.

Table 2 indicates that the cross-country differences in employment rates between the countries are quite large among older people under 70, whereas not many people aged between 70 and 75 were employed in the urban regions of the two countries. Not surprisingly, we also observe that healthy seniors have higher employment rates than their unhealthy peers for all 3 years and both countries. It is worth noting that as many as $43 \%$ healthy Russian seniors worked in 2018, whereas this was the case for not more than 16\% in urban China, a difference of $27 \%$. Russian seniors with a low education level had a lower employment rate than other Russian seniors. Such a pattern is also found among the Chinese samples in 2002 and 2018.

To understand why some seniors work and others do not, we have estimated logit models using the CHIP and the RLMS data. We applied the independent variables introduced in Table 2. ${ }^{14}$ The estimates are reported in Table 3. For all the six equations, we report three

12 In our data, we can observe the working hours of each individual. In all the samples, the differences between seniors and non-seniors are small. The largest difference is in the Russian sample for 2013, in which seniors worked 7.8 hours per day on average compared with 8.8 hours per day for non-seniors.

13 The Russian surveys also included some other questions, making it possible to apply a broader definition of working for earnings. This is not possible in the Chinese surveys. If a positive answer to at least one of the questions used for the working definition is included, the estimate of the fraction working among the elderly population in urban Russia would increase by, for example, $4 \%$ in 2002 and 3\% in 2013. The increase in the employment rate among seniors in urban China that we report between 2002 and 2013 is consistent with Liu (2013).

14 We assume that the reason for the "none pension" record in our data is that the individual did not receive any pension during the year. As we arranged the variable pensions into a logarithmic form, we substituted the zeros with the lowest value observed in the sample the same year. 
Table 2 Employment rates for older people in urban China and urban Russia in 2002, 2013, and 2018 (\%)

\begin{tabular}{|c|c|c|c|c|c|c|c|}
\hline & & $\begin{array}{c}\text { China } \\
2002\end{array}$ & $\begin{array}{c}\text { China } \\
2013\end{array}$ & $\begin{array}{c}\text { China } \\
2018\end{array}$ & $\begin{array}{c}\text { Russia } \\
2002\end{array}$ & $\begin{array}{c}\text { Russia } \\
2013\end{array}$ & $\begin{array}{c}\text { Russia } \\
2018\end{array}$ \\
\hline \multirow[t]{2}{*}{ Gender } & Female & 5.47 & 9.48 & 10.37 & 15.57 & 23.93 & 25.97 \\
\hline & Male & 5.47 & 12.82 & 15.46 & 20.37 & 21.98 & 24.36 \\
\hline \multirow[t]{3}{*}{ Living arrangements } & Living alone & 12.70 & 6.10 & 13.58 & 10.62 & 19.99 & 22.68 \\
\hline & Couples & 6.82 & 14.84 & 16.92 & 16.89 & 18.57 & 23.51 \\
\hline & All other living arrangements & 4.63 & 9.38 & 10.75 & 19.98 & 28.21 & 28.21 \\
\hline \multirow[t]{2}{*}{ Age } & $55 / 60-70$ & 6.96 & 14.41 & 16.74 & 27.41 & 35.48 & 29.84 \\
\hline & $70-75$ & 1.39 & 2.40 & 2.77 & 1.97 & 5.21 & 7.87 \\
\hline \multirow[t]{4}{*}{ Education } & Low & 1.92 & 10.59 & 12.75 & 6.34 & 10.01 & 17.35 \\
\hline & Upper middle & 6.13 & 11.56 & 11.98 & 16.75 & 25.85 & 22.75 \\
\hline & Polytechnic & 8.58 & 6.30 & 7.80 & 34.80 & 25.05 & 25.59 \\
\hline & Higher & 13.97 & 11.47 & 15.82 & 20.30 & 32.71 & 32.55 \\
\hline \multirow[t]{3}{*}{ City size } & Large & 14.72 & 4.93 & 6.37 & 19.31 & 24.31 & 27.03 \\
\hline & Middle & 5.16 & 9.19 & 14.95 & 14.01 & 23.02 & 24.38 \\
\hline & Small & 4.62 & 12.71 & 12.28 & 11.23 & 19.00 & 17.39 \\
\hline \multirow[t]{3}{*}{ Health status } & Healthy (good and very good) & 7.55 & 15.65 & 16.32 & 23.00 & 43.65 & 42.67 \\
\hline & Not good, not bad & 5.05 & 7.34 & 9.63 & 32.97 & 28.43 & 28.78 \\
\hline & Not healthy (bad and very bad) & 1.42 & 5.15 & 4.95 & 5.29 & 8.97 & 11.16 \\
\hline \multirow{4}{*}{$\begin{array}{l}\text { Employment rate by } \\
\text { quantiles of pensions } \\
\text { (from low to high) }\end{array}$} & First & 11.02 & 19.17 & 32.36 & 10.61 & 29.69 & 35.46 \\
\hline & Second & 3.17 & 20.47 & 19.92 & 20.55 & 26.49 & 27.68 \\
\hline & Third & 4.09 & 18.85 & 13.67 & 25.49 & 19.88 & 26.65 \\
\hline & Fourth & 3.65 & 5.90 & 3.84 & 9.17 & 15.78 & 11.57 \\
\hline \multicolumn{2}{|c|}{ Employment rate among elderly respondents } & 5.47 & 10.81 & 12.42 & 16.88 & 23.40 & 25.51 \\
\hline
\end{tabular}

Note: The table refers to women over 55 years old and men over 60 years old, with both being at most 75 years old. Source: Authors' calculations from the CHIP and the RLMS data.

CHIP, China Household Income Project; RLSM, Russian Longitudinal Monitoring Survey.

factors that are positively related to the probability of working for pay after the normal retirement age, namely, living with a spouse, being in good health, and having a high education level. As in the Russian sample for 2002, being female is associated with a lower probability of working as a senior in all the three Chinese samples. In all samples, we report a clear pattern that the probability of employment is negatively related to age and pension size. ${ }^{15}$ According to these results, we infer that the individual factors that are related to working beyond the normal retirement age appear to be similar in urban China and urban Russia, and possibly also in high-income countries. For the Chinese samples we also included a variable indicating the proportion migrants in the city. The estimates show a negative coefficient indicating that the larger proportion migrants in a Chinese city, the lower is the probability that a senior work.

15 In the Chinese samples, it was possible to investigate whether additional factors were related to working after reaching the statutory retirement age. Alternative specifications include, for example, a variable measuring housing wealth, which implies a negative association between this variable and the probability of working after reaching the normal retirement age. We also found a positive relationship between the share of disabled individuals, the number of children within the household, and the probability of working after normal retirement age. 
Table 3 Estimates of employment probabilities for older people in urban China and urban Russia

\begin{tabular}{|c|c|c|c|c|c|c|c|}
\hline & & $\begin{array}{l}\text { China } \\
2002\end{array}$ & $\begin{array}{l}\text { China } \\
2013\end{array}$ & $\begin{array}{l}\text { China } \\
2018\end{array}$ & $\begin{array}{c}\text { Russia } \\
2002\end{array}$ & $\begin{array}{c}\text { Russia } \\
2013\end{array}$ & $\begin{array}{c}\text { Russia } \\
2018\end{array}$ \\
\hline $\begin{array}{l}\text { Gender (male } \\
\text { omitted) }\end{array}$ & Female & $\begin{array}{l}-0.53^{\star \star} \\
(0.230)\end{array}$ & $\begin{array}{l}-0.77^{\star \star \star} \\
(0.123)\end{array}$ & $\begin{array}{l}-1.03^{\star \star \star} \\
(0.091)\end{array}$ & $\begin{array}{c}-0.56^{\star \star \star} \\
(0.158)\end{array}$ & $\begin{array}{l}-0.11 \\
(0.119)\end{array}$ & $\begin{array}{r}-0.165 \\
(0.142)\end{array}$ \\
\hline \multirow{2}{*}{$\begin{array}{l}\text { Household } \\
\text { structure (all other } \\
\text { living arrangements } \\
\text { omitted) }\end{array}$} & Living alone & $\begin{array}{l}1.09 * \star \\
(0.451)\end{array}$ & $\begin{array}{l}-0.30 \\
(0.534)\end{array}$ & $\begin{array}{l}0.49^{\star \star} \\
(0.217)\end{array}$ & $\begin{array}{l}0.62^{\star \star} \\
(0.288)\end{array}$ & $\begin{array}{l}-0.43 \\
(0.273)\end{array}$ & $\begin{array}{l}-0.15 \\
(0.162)\end{array}$ \\
\hline & Couples & $\begin{array}{l}0.63^{\star \star \star} \\
(0.443) \\
\end{array}$ & $\begin{array}{l}0.89^{\star \star \star} \\
(0.101) \\
\end{array}$ & $\begin{array}{l}0.52^{\star \star \star} \\
(0.099) \\
\end{array}$ & $\begin{array}{c}0.27^{\star \star} \\
(0.105) \\
\end{array}$ & $\begin{array}{c}0.26^{\star \star} \\
(0.104) \\
\end{array}$ & $\begin{array}{l}0.29 \star \star \star \\
(0.139) \\
\end{array}$ \\
\hline $\begin{array}{l}\text { Age (55/60-70 } \\
\text { omitted) }\end{array}$ & $70-75$ & $\begin{array}{l}-1.46^{\star \star \star} \\
(0.301)\end{array}$ & $\begin{array}{l}-1.98^{\star \star \star} \\
(0.204)\end{array}$ & $\begin{array}{l}-2.13^{\star \star \star} \\
(0.176)\end{array}$ & $\begin{array}{l}-1.78^{\star \star \star} \\
(0.217)\end{array}$ & $\begin{array}{l}-1.88^{\star \star \star} \\
(0.143)\end{array}$ & $\begin{array}{l}-1.28^{\star \star \star} \\
(0.218)\end{array}$ \\
\hline \multirow[t]{3}{*}{$\begin{array}{l}\text { Education (lower } \\
\text { education omitted) }\end{array}$} & Upper middle & $\begin{array}{l}1.68^{\star \star \star} \\
(0.305)\end{array}$ & $\begin{array}{r}0.141^{\star} \\
(0.134)\end{array}$ & $\begin{array}{l}0.02 \\
(0.095)\end{array}$ & $\begin{array}{l}0.60^{\star \star} \\
(0.240)\end{array}$ & $\begin{array}{l}1.27^{\star \star \star} \\
(0.311)\end{array}$ & $\begin{array}{l}0.06 \\
(0.208)\end{array}$ \\
\hline & Polytechnic & $\begin{array}{l}2.29^{\star \star \star} \\
(0.317)\end{array}$ & $\begin{array}{l}0.69^{\star \star \star} \\
(0.228)\end{array}$ & $\begin{array}{l}0.47^{\star \star \star} \\
(0.141)\end{array}$ & $\begin{array}{l}0.91^{\star \star \star} \\
(0.179)\end{array}$ & $\begin{array}{l}1.57^{\star \star \star} \\
(0.299)\end{array}$ & $\begin{array}{l}0.42^{\star \star} \\
(0.201)\end{array}$ \\
\hline & Higher & $\begin{array}{l}2.49^{\star \star \star} \\
(0.326)\end{array}$ & $\begin{array}{l}0.061^{\star \star \star} \\
(0.176)\end{array}$ & $\begin{array}{l}0.96^{\star \star \star} \\
(0.155)\end{array}$ & $\begin{array}{l}1.54^{\star \star \star} \\
(0.301)\end{array}$ & $\begin{array}{l}1.60^{\star \star \star} \\
(0.327)\end{array}$ & $\begin{array}{l}0.89^{\star \star \star} \\
(0.204)\end{array}$ \\
\hline \multirow[t]{2}{*}{$\begin{array}{l}\text { City size (small } \\
\text { omitted) }\end{array}$} & Large & $\begin{array}{l}1.26^{\star \star \star} \\
(0.167)\end{array}$ & $\begin{array}{l}0.88^{\star \star \star} \\
(0.215)\end{array}$ & $\begin{array}{l}0.35^{\star \star} \\
(0.167)\end{array}$ & $\begin{array}{l}0.66^{\star \star \star} \\
(0.156)\end{array}$ & $\begin{array}{l}0.01 \\
(0.117)\end{array}$ & $\begin{array}{l}1.44^{\star \star \star} \\
(0.275)\end{array}$ \\
\hline & Middle & $\begin{array}{c}0.27 \\
(0.255) \\
\end{array}$ & $\begin{array}{l}-0.18 \\
(0.191) \\
\end{array}$ & $\begin{array}{r}0.18^{\star \star} \\
(0.088) \\
\end{array}$ & $\begin{array}{l}0.71^{\star \star \star} \\
(0.248) \\
\end{array}$ & $\begin{array}{l}-0.05 \\
(0.166) \\
\end{array}$ & $\begin{array}{l}1.06^{\star \star \star} \\
(0.285)\end{array}$ \\
\hline \multirow[t]{2}{*}{$\begin{array}{l}\text { Health status } \\
\text { (healthy omitted) }\end{array}$} & $\begin{array}{l}\text { Relatively healthy } \\
\text { (not good and not } \\
\text { bad) }\end{array}$ & $\begin{array}{l}-0.31 \\
(0.258)\end{array}$ & $\begin{array}{l}-0.75^{\star \star \star} \\
(0.117)\end{array}$ & $\begin{array}{l}-0.34^{\star \star \star} \\
(0.090)\end{array}$ & $\begin{array}{l}-0.83^{\star \star \star} \\
(0.263)\end{array}$ & $\begin{array}{l}-0.55^{\star \star \star} \\
(0.156)\end{array}$ & $\begin{array}{l}-1.63^{\star \star \star} \\
(0.236)\end{array}$ \\
\hline & Not healthy & $\begin{array}{l}-1.58^{\star \star \star} \\
(0.403)\end{array}$ & $\begin{array}{l}-0.96^{\star \star \star} \\
(0.234)\end{array}$ & $\begin{array}{l}-1.15^{\star \star \star} \\
(0.177)\end{array}$ & $\begin{array}{l}-1.60^{\star \star \star} \\
(0.291)\end{array}$ & $\begin{array}{l}-1.54^{\star \star \star} \\
(0.184)\end{array}$ & $\begin{array}{c}-0.57^{\star \star \star} \\
(0.187)\end{array}$ \\
\hline Log of pension & & $\begin{array}{l}-0.087^{\star \star \star} \\
(0.022)\end{array}$ & $\begin{array}{l}-0.030^{\star \star \star} \\
(0.009)\end{array}$ & $\begin{array}{l}-0.048^{\star \star \star} \\
(0.0028)\end{array}$ & $\begin{array}{l}-0.046^{\star \star \star} \\
(0.0028)\end{array}$ & $\begin{array}{c}-0.032^{\star \star \star} \\
(0.0024)\end{array}$ & $\begin{array}{l}-1.46^{\star \star \star} \\
(0.179)\end{array}$ \\
\hline \multicolumn{2}{|c|}{ Yearly working hours/100 } & $\begin{array}{l}0.03^{\star \star \star} \\
(0.000)\end{array}$ & $\begin{array}{l}0.03^{\star \star \star} \\
(0.000)\end{array}$ & $\begin{array}{l}0.02^{\star \star \star} \\
(0.000)\end{array}$ & & & \\
\hline \multicolumn{2}{|c|}{ Rate of migrants in the city } & $\begin{array}{l}-0.03^{\star} \\
(0.015)\end{array}$ & $\begin{array}{l}-0.01^{\star \star} \\
(0.005)\end{array}$ & $\begin{array}{c}-0.02^{\star \star \star} \\
(0.003)\end{array}$ & & & \\
\hline \multicolumn{2}{|l|}{ Constant } & $\begin{array}{c}-2.50^{\star \star \star} \\
(0.358)\end{array}$ & $\begin{array}{c}-0.85^{\star \star} \\
(0.1779)\end{array}$ & $\begin{array}{c}-0.06 \\
(0.123)\end{array}$ & $\begin{array}{c}-0.90^{\star} \\
(0.507)\end{array}$ & $\begin{array}{l}-1.54^{\star \star \star} \\
(0.427)\end{array}$ & $\begin{array}{l}12.308^{\star \star \star} \\
(2.109)\end{array}$ \\
\hline \multicolumn{2}{|c|}{ Number of observations } & 2,406 & 3,340 & 6,885 & 1,582 & 3,174 & 1,749 \\
\hline \multicolumn{2}{|l|}{ Pseudo $\mathbf{R}^{2}$} & 0.2156 & 0.1294 & 0.2352 & 0.1749 & 0.1730 & 0.1178 \\
\hline
\end{tabular}

Note: ${ }^{\star \star \star}$ represents $p<0.01 ;{ }^{* \star}$ represents $p<0.05$; ${ }^{\star}$ represents $p<0.10$.

Source: Authors' estimates from the CHIP and the RLMS data.

CHIP, China Household Income Project; RLSM, Russian Longitudinal Monitoring Survey.

\section{The Labor Market for Older Workers}

We now turn to the means by which differences in the labor markets in urban China and urban Russia can be used to explain why the proportion of seniors who work beyond the normal retirement age is higher in Russia than in urban China. Our data demonstrate that elderly workers earn considerably less than non-elderly workers. This is true in both urban China and urban Russia. ${ }^{16}$ To some extent, however, this can be attributed to differences in the characteristics of

16 For example, the earnings gap in urban China was $47 \%$ in 2002 and $56 \%$ in 2013, whereas in urban Russia it was $65 \%$ in 2002 and 32\% in 2013. 
elderly workers and other workers. For example, elderly workers have, on average, a lower education level than younger workers. Therefore, we treated yearly earnings in the 2013 constant price as the dependent variable and estimated log earnings functions for workers aged between 40/45 and 75 in each of the four samples (see Table 4). Our focus is on the age dummies for the groups that are, respectively, aged 55/60 to 69 and 70 to 75 . Two specifications were applied. In addition to the age dummies, the first specification includes dummies for gender, education, and city size as explanatory variables. In the second specification, we add dummies for occupation, economic sector (not available for urban Russia 2002), and firm ownership.

The results are reported in Tables $4 \mathrm{a}$ and $4 \mathrm{~b}$. In all six samples, the negative coefficients for being over the normal retirement age are statistically significant. Comparing the two specifications, we find that the coefficients for the age dummies are not surprisingly lower when occupation, economic sector, and ownership type are included. However, the reduction is not large, particularly for the Russian samples. The negative coefficients on the dummies for being between 55/60 and 70 years old are much larger for the Chinese samples. As discussed in Section 4, we interpret this as an evidence for the greater effect of the normal retirement age on a person's working life in urban China because elderly Chinese workers face much higher competition from younger, less qualified, migrant workers. This interpretation is further strengthened when we estimate quantile regressions. In Figure 4, we demonstrate that being over the normal retirement age has the largest negative association with earnings at the lower

Table 4 The relationship between age and earnings obtained from the earnings function for workers aged $40 / 45$ and over in urban China and urban Russia in 2002, 2013, and 2018

Table 4a Parsimonious specification

\begin{tabular}{|c|c|c|c|c|c|c|c|}
\hline & & $\begin{array}{l}\text { China } \\
2002\end{array}$ & $\begin{array}{l}\text { China } \\
2013\end{array}$ & $\begin{array}{l}\text { China } \\
2018\end{array}$ & $\begin{array}{c}\text { Russia } \\
2002\end{array}$ & $\begin{array}{c}\text { Russia } \\
2013\end{array}$ & $\begin{array}{c}\text { Russia } \\
2018\end{array}$ \\
\hline Gender (male omitted) & Female & $\begin{array}{l}-0.29 * \star \star \\
(0.029)\end{array}$ & $\begin{array}{l}-0.40^{\star \star \star} \\
(0.040)\end{array}$ & $\begin{array}{l}-0.51^{\star \star \star} \\
(0.032)\end{array}$ & $\begin{array}{l}-0.344^{\star \star \star} \\
(0.051)\end{array}$ & $\begin{array}{l}-0.272^{\star \star \star} \\
(0.030)\end{array}$ & $\begin{array}{l}-0.26^{\star \star \star} \\
(0.034)\end{array}$ \\
\hline \multirow[t]{2}{*}{ Age (40/45-55/60 omitted) } & $55 / 60-70$ & $\begin{array}{l}-1.44^{\star \star \star} \\
(0.054)\end{array}$ & $\begin{array}{l}-1.60 \star \star \star \\
(0.057)\end{array}$ & $\begin{array}{l}-1.68^{\star \star \star} \\
(0.046)\end{array}$ & $\begin{array}{l}-0.151^{\star \star \star} \\
(0.051)\end{array}$ & $\begin{array}{l}-0.326^{\star \star \star} \\
(0.031)\end{array}$ & $\begin{array}{l}-0.30^{\star \star \star} \\
(0.037)\end{array}$ \\
\hline & $70-75$ & $\begin{array}{l}-2.92^{\star \star \star} \\
(0.143)\end{array}$ & $\begin{array}{l}-2.83^{\star \star \star} \\
(0.110)\end{array}$ & $\begin{array}{l}-3.20^{\star \star \star} \\
(0.095)\end{array}$ & $\begin{array}{l}-0.422^{\star \star \star} \\
(0.125)\end{array}$ & $\begin{array}{l}-0.781^{\star \star \star} \\
(0.105)\end{array}$ & $\begin{array}{l}-0.62^{\star \star \star} \\
(0.120)\end{array}$ \\
\hline \multirow[t]{3}{*}{$\begin{array}{l}\text { Education (lower } \\
\text { education omitted) }\end{array}$} & Upper middle & $\begin{array}{l}0.31^{\star \star \star} \\
(0.061)\end{array}$ & $\begin{array}{l}0.06 \\
(0.065)\end{array}$ & $\begin{array}{l}0.04 \\
(0.051)\end{array}$ & $\begin{array}{c}0.085 \\
(0.095)\end{array}$ & $\begin{array}{l}0.112^{\star \star} \\
(0.049)\end{array}$ & $\begin{array}{l}0.06 \\
(0.052)\end{array}$ \\
\hline & Polytechnic & $\begin{array}{l}0.78^{\star \star \star} \\
(0.064)\end{array}$ & $\begin{array}{l}0.65^{\star \star \star} \\
(0.091)\end{array}$ & $\begin{array}{l}0.45^{\star \star \star} \\
(0.077)\end{array}$ & $\begin{array}{l}0.518^{\star \star \star} \\
(0.093)\end{array}$ & $\begin{array}{l}0.227^{\star \star \star} \\
(0.049)\end{array}$ & $\begin{array}{l}0.12^{\star \star} \\
(0.052)\end{array}$ \\
\hline & Higher & $\begin{array}{l}1.14^{\star \star \star} \\
(0.082)\end{array}$ & $\begin{array}{l}0.96^{\star \star \star} \\
(0.074)\end{array}$ & $\begin{array}{l}1.13^{\star \star \star} \\
(0.057)\end{array}$ & $\begin{array}{l}0.248^{\star \star \star} \\
(0.093)\end{array}$ & $\begin{array}{l}0.570^{\star \star \star} \\
(0.050)\end{array}$ & $\begin{array}{l}0.38^{\star \star \star} \\
(0.052)\end{array}$ \\
\hline Constant & & $\begin{array}{l}8.83^{\star \star \star} \\
(0.061) \\
\end{array}$ & $\begin{array}{c}9.77^{\star \star \star} \\
(0.065)\end{array}$ & $\begin{array}{l}9.98^{\star \star \star} \\
(0.053)\end{array}$ & $\begin{array}{c}8.785 \\
(0.163) \\
\end{array}$ & $\begin{array}{c}9.797 \\
(0.066) \\
\end{array}$ & $\begin{array}{c}10.23^{\star \star \star} \\
(0.086)\end{array}$ \\
\hline $\mathrm{R}^{2}$ & & 0.267 & 0.341 & 0.352 & 0.102 & 0.178 & 0.145 \\
\hline Number of observations & & 4,977 & 4,310 & 7,574 & 1,182 & 2,542 & 1,675 \\
\hline
\end{tabular}

Note: (1) Estimates based on samples of workers aged $\geq 40 / 45$. The dependent variable is log earnings. The specification also includes two dummies for city size (with small city treated as omitted category). (2) *** represents $p<0.01 ;{ }^{* *}$ represents $p<0.05 ;{ }^{*}$ represents $p<0.10$.

Source: Authors' estimates from the CHIP and the RLMS data.

CHIP, China Household Income Project; RLMS, Russian Longitudinal Monitoring Survey. 
Table 4b Extended specification

\begin{tabular}{|c|c|c|c|c|c|c|c|}
\hline & & $\begin{array}{l}\text { China } \\
2002\end{array}$ & $\begin{array}{l}\text { China } \\
2013\end{array}$ & $\begin{array}{l}\text { China } \\
2018\end{array}$ & $\begin{array}{c}\text { Russia } \\
2002\end{array}$ & $\begin{array}{c}\text { Russia } \\
2013\end{array}$ & $\begin{array}{c}\text { Russia } \\
2018\end{array}$ \\
\hline Gender (male omitted) & Female & $\begin{array}{l}-0.14^{\star \star \star} \\
(0.027)\end{array}$ & $\begin{array}{l}-0.26^{\star \star \star} \\
(0.038)\end{array}$ & $\begin{array}{l}-0.34^{\star \star \star} \\
(0.028)\end{array}$ & $\begin{array}{l}-0.394^{\star \star \star} \\
(0.050)\end{array}$ & $\begin{array}{l}-0.237^{\star \star \star} \\
(0.032)\end{array}$ & $\begin{array}{l}-0.215^{\star \star \star} \\
(0.035)\end{array}$ \\
\hline \multirow[t]{2}{*}{ Age (40/45-55/60 omitted) } & $55 / 60-70$ & $\begin{array}{l}-0.99 * \star \star \\
(0.052)\end{array}$ & $\begin{array}{l}-1.03^{\star \star \star} \\
(0.057)\end{array}$ & $\begin{array}{l}-0.90 * \star \star \\
(0.047)\end{array}$ & $\begin{array}{l}-0.111^{\star \star} \\
(0.052)\end{array}$ & $\begin{array}{l}-0.284^{\star \star \star} \\
(0.030)\end{array}$ & $\begin{array}{l}-0.272^{\star \star \star} \\
(0.036)\end{array}$ \\
\hline & $70-75$ & $\begin{array}{l}-2.33^{\star \star \star} \\
(0.132)\end{array}$ & $\begin{array}{l}-1.90^{\star \star \star} \\
(0.109)\end{array}$ & $\begin{array}{l}-1.11^{\star \star \star} \\
(0.180)\end{array}$ & $\begin{array}{l}-0.404^{\star \star \star} \\
(0.130)\end{array}$ & $\begin{array}{l}-0.713^{\star \star \star} \\
(0.095)\end{array}$ & $\begin{array}{l}-0.547^{\star \star \star} \\
(0.115)\end{array}$ \\
\hline \multirow[t]{3}{*}{$\begin{array}{l}\text { Education (lower educa- } \\
\text { tion omitted) }\end{array}$} & Upper middle & $\begin{array}{l}0.21^{\star \star \star} \\
(0.056)\end{array}$ & $\begin{array}{l}0.02 \\
(0.060)\end{array}$ & $\begin{array}{l}0.13^{\star \star \star} \\
(0.047)\end{array}$ & $\begin{array}{c}0.093 \\
(0.091)\end{array}$ & $\begin{array}{l}0.099^{\star \star} \\
(0.047)\end{array}$ & $\begin{array}{c}0.058 \\
(0.050)\end{array}$ \\
\hline & Polytechnic & $\begin{array}{l}0.44^{\star \star \star} \\
(0.060)\end{array}$ & $\begin{array}{l}0.40^{\star \star \star} \\
(0.087)\end{array}$ & $\begin{array}{l}0.48^{\star \star \star} \\
(0.069)\end{array}$ & $\begin{array}{l}0.347^{\star \star \star} \\
(0.097)\end{array}$ & $\begin{array}{l}0.183^{\star \star \star} \\
(0.047)\end{array}$ & $\begin{array}{l}0.093^{\star \star} \\
(0.040)\end{array}$ \\
\hline & Higher & $\begin{array}{l}0.68^{\star \star \star} \\
(0.073)\end{array}$ & $\begin{array}{l}0.58^{\star \star \star} \\
(0.073)\end{array}$ & $\begin{array}{l}0.87^{\star \star \star} \\
(0.057)\end{array}$ & $\begin{array}{c}0.164^{\star} \\
(0.091)\end{array}$ & $\begin{array}{l}0.455^{\star \star \star} \\
(0.052)\end{array}$ & $\begin{array}{l}0.368^{\star \star \star} \\
(0.062)\end{array}$ \\
\hline Constant & & $\begin{array}{l}8.25^{\star \star \star} \\
(0.059)\end{array}$ & $\begin{array}{l}8.78^{\star \star \star} \\
(0.074)\end{array}$ & $\begin{array}{l}9.72^{\star \star \star} \\
(0.071)\end{array}$ & $\begin{array}{r}8.860 \\
(0.176) \\
\end{array}$ & $\begin{array}{c}9.684 \\
(0.080) \\
\end{array}$ & $\begin{array}{c}10.127^{\star \star \star} \\
(0.098)\end{array}$ \\
\hline $\mathrm{R}^{2}$ & & 0.396 & 0.436 & 0.305 & 0.1429 & 0.2557 & 0.2255 \\
\hline Observations & & 4,977 & 4,310 & 6,531 & 1,182 & 2,542 & 1,675 \\
\hline
\end{tabular}

Note: (1) Estimates based on samples of workers aged $\geq 40 / 45$. The dependent variable is log earnings. The specification also includes two dummies for city size (with small cities as omitted category), three dummies for occupation (manual workers as omitted category), five dummies for economic sector (manufacturing as omitted category), and three dummies for ownership type (with others as omitted category). (2) ${ }^{\star \star \star}$ represents $p<0.01$; ${ }^{\star \star}$ represents $p<0.05 ;{ }^{\star}$ represents $p<0.1$.

Source: Author's estimates from the CHIP and the RLMS data.

CHIP, China Household Income Project; RLMS, Russian Longitudinal Monitoring Survey.

Figure 4 Quintile regression coefficients on age from earnings equations by percentiles.

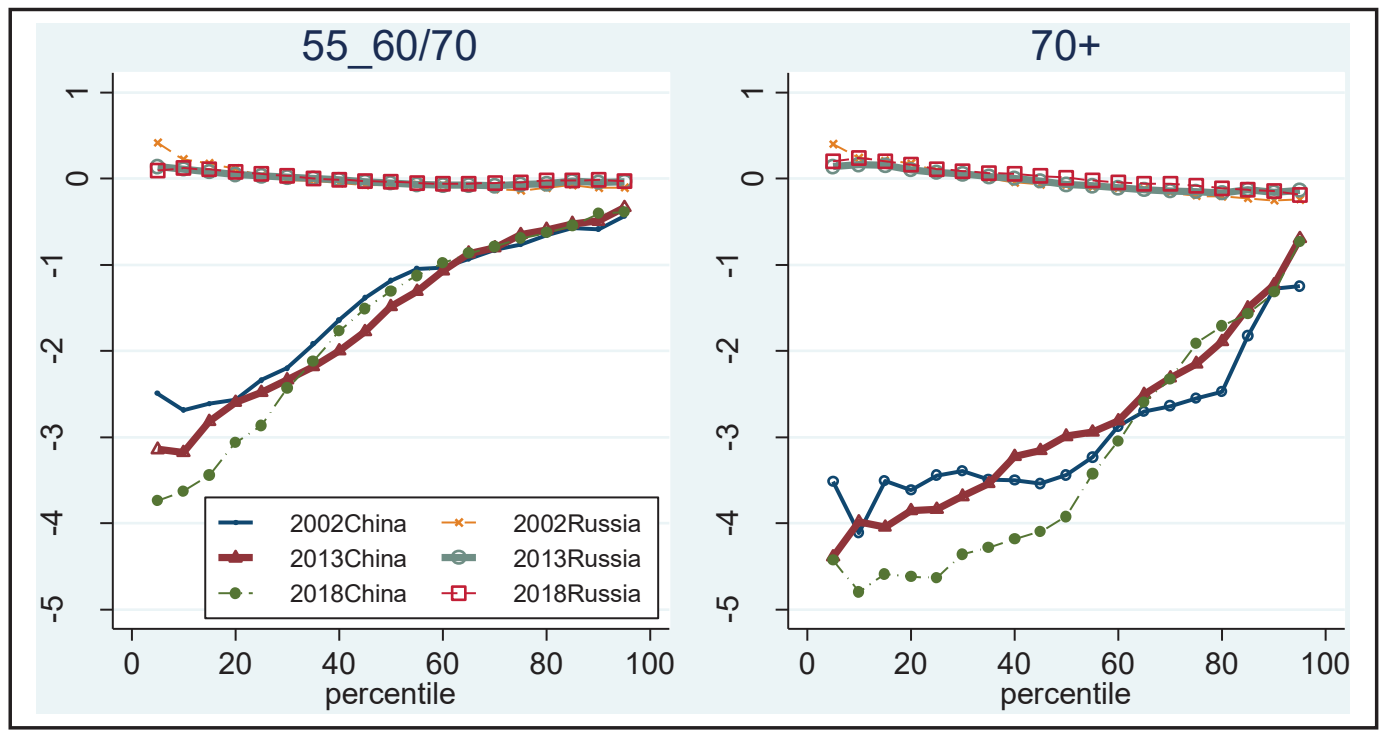

Note: The estimates are from the specifications available in Table 4a.

Source: Authors' estimates from the CHIP and RLMS. CHIP, China Household Income Project; RLMS, Russian Longitudinal Monitoring Survey 
percentiles in urban China, but that this is not the case in urban Russia. The large negative coefficients for being between 70 and 75 in all six samples reported in Table 4 should be viewed in the context of the fact that not many workers are of that age and that our data demonstrate that they tend to work fewer hours than other working seniors.

We have thus found several indications of that differences in the labour market between urban China and urban Russia are important reasons why a larger proportion of older persons work after the normal retirement age. In the previous section we found for China that the larger proportion migrants in the local labour market the less likely is that a person over the general retirement age is working. In this section we have found that being over the general retirement age has larger wage concequences in urban China than in urban Russia, and that those consequences are concentrated at the lower part of the wage distribution.

\section{Summary and Conclusions}

In this article, we have studied the facts-and their statistical significance-relating to seniors working beyond the normal pension age, which is at 55 for females and 60 for males in the urban regions of China and Russia, the two largest countries that have had a socialist economic system. We used micro-data for 2002, 2013, and 2018 and asked, "What is the incidence of working beyond the normal retirement age in each of these two countries?" We have demonstrated that the incidence has increased over the years investigated in both countries. In urban Russia, no less than $26 \%$ seniors aged up to 75 were employed in 2018 , whereas only $12 \%$ older people were employed in urban China in the same year. Thus, we document that it is considerably more common to work after reaching the normal retirement age in urban Russia than in urban China.

By estimating logit models, we investigated the characteristics of those who work for earnings beyond the normal retirement age in the six samples. In each of the samples we reported clear evidence that those who are under 70 , those who live with a spouse only, those who are healthy, and those with a higher education level have higher probabilities of working than others. In all cases, we observed that the probability of working for earnings was negatively related to the size of the pension received. We also reported that being female decreased the working probability in all three samples from urban China, but in contrast, in not more than one of the samples for urban Russia. From these results, we conclude that the individual determinants of working for earnings among seniors in urban China and urban Russia are broadly similar, and are also similar to what has been observed in the literature with regard to high-income countries.

We also attempted to shed light on why it is more common for seniors in urban Russia to work when compared with their counterparts in urban China. It is likely that several cross-country differences are important; however, the available literature on the variations on seniors' labor-supply decisions across countries has not yet been developed. In this study, we are able to rule out the influence of two differences in population composition between urban China and urban Russia and cross-country differences in health status and age distribution of people aged between 55/60 and 75. This is because several facts support that Chinese seniors are actually healthier than Russian seniors, and persons in the studied age-brackets in urban China are younger than their Russian counterparts. 
We have discussed three societal differences that could explain why a larger proportion of urbanites in Russia work beyond the normal retirement age. One reason is differences in macroeconomic experiences over the recent decades, which could have affected expectations for the future. The Chinese economy has experienced rather high rates of economic growth for a long time, whereas Russia had significant negative economic growth rates in the 1990s after the collapse of Soviet Union. Another difference between urban China and urban Russia, which is potentially of relevance for the number of seniors who work beyond the normal retirement age, is differences in family arrangements and norms. For example, sharing households with an adult child is more common in urban China than in urban Russia. More research on the importance of each of these two factors is suggested.

In this article, we provide evidence that yet another cross-country difference between urban China and urban Russia is probably crucial in explaining why a larger proportion of older urbanites in Russia work for earnings when compared with China; this proportion represents the cross-country differences in the labor market that prevails for older workers. We have demonstrated that older workers in urban China are at a substantial wage disadvantage compared to younger workers even with the same characteristics, but this is not to the same extent the case in urban Russia. The normal retirement age is more forcefully implemented in urban China and seniors in urban China are, to a much larger extent, competing for jobs with rural-to-urban migrants.

Our results may encourage policy debates and policymaking. One lesson is that urban China can learn from the Russian situation that a considerably larger proportion of heathy people under 70 should be able to work for earnings. Several measures can be taken to increase the employment rate among such persons. Such measures can aim to decrease segmentation between rural-to-urban migrants and urban residents in China's urban labor market. There are also arguments in favor of making the transition from working to retirement gradual and flexible in urban China and to encourage the employed to continue to work after having reached the normal retirement age. It is also worth mentioning that making out-of-home childcare in urban China more attractive will make it possible for middle-aged and older workers (mainly females) to stay at work after becoming a grandparent. However, China can also learn from the recent Russian experience in 2018, when the normal retirement age was increased to 60 for females and 65 for males, that such a change can be extremely unpopular.

\section{Acknowledgements}

Earlier versions of the paper were presented at University of Örebro, Sweden and at the IZA-HSE University International Labor Seminar, September 2020. When revising the paper we have benefited from comments at the seminar by Heltmut Lehman, Oxana Sinyavskaya and Feicheng Wang and also from referees to this journal.

\section{Funding}

The participation of Ludmila Nivorozhkina was supported by the financial support of the Russian Foundation for Basic Research in the framework of the research project 19-010-00009. 


\section{References}

Alexander, P.; A. Chan (2004): Does China have an Apartheid Pass System? Journal of Ethnic and Migration Studies 30(4), 609-629.

Alexeev, M.; S. Weber (2013): The Oxford Handbook of the Russian Economy. Oxford: Oxford University Press.

Anxo, D.; T. Ericson; A. Herbert (2019): Beyond Retirement: Who Stays at Work after the Standard Age of Retirement. International Journal of Manpower 40(5), 917-938.

Arnstein, A.; B. Arpino; A. Goisis (2012): Grandparenting and Mothers' Labour Force Participation: A Comparative Analysis Using the Generations and Gender Survey. Demographic Research 27, 53-84.

Brandt, M. (2018): Carrot and Stick: How It was Possible to Raise the Retirement Age in Russia. Russia Analytic Digest No. 225, 2-9. https://www.research-collection.ethz.ch/bitstream/handle/20.500.11850/293825/2/ RAD_225.pdf.

Cai, F.; J. Giles; X. Meng (2006): How Well Do Children Insure Parents against Low Retirement Income? An Analysis Using Survey Data from Urban China. Journal of Public Economics 90(12), 2229-2255.

Dingemans, E.; K. Henkens (2020): Job Strain in Working Retirees in Europe: A Latent Class Analysis. Aging \& Society 40, 2014-2060.

Dingemans, E.; K. Henkens; H. van Solinge (2017): Working Retirees in Europe: Individual and Societal Determinants. Work, Employment and Society 31(6), 972-991.

Du, F.; X. Dong; Y. Zhang, Y. (2019): Grandparent-provided Childcare and Labor Force Participation of Mothers with Preschool Children in Urban China. China Population and Development Studies 2(3), 347-368.

Eurostat (2019): Employment Rates by Sex, Age and Citizenship (\%). https://appsso.eurostat.ec.europa.eu/ nui/submitViewTableAction.do. Accessed 11 December 2019.

Federal State Statistic Service - Rosstat (2018): http://www.gks.ru/wps/wcm/connect/rosstat_main/rosstat/ $\mathrm{ru} / \mathrm{statistics/population/level}$

Feng J.; Q. Li; J. P. Smith (2020): Retirement Effect on Health Status and Health Behaviors in Urban China. World Development 126. 104702.

Gerber, T. P.; J. Radl (2014): Pushed, Pulled, or Blocked? The Elderly and the Labor Market in Post-Soviet Russia. Social Science Research 45, 152-169.

Gilles, J.; Yan Shen; John Strauss; Yaohui Zhao (2012): The Labor Supply and Retirement Behavior of China's Older Workers and Elderly in Comparative Perspective, Chapter 6, in: Smith, J.; M. Majmunder (eds.), Ageing in Asia. Washington D.C.: National Academic Press. https://www.ncbi.nlm.nih.gov/books/NBK109233/.

Gustafsson, B.; S. Li; H. Sato (2014): Data for Studying Earnings, the Distribution of Household Income and Poverty in China. China Economic Review 30, 419-431.

Hsieh, N. (2015): Economic Security, Social Cohesion, and Depression Disparities in Post-transition Societies: A Comparison of Older Adults in China and Russia. Journal of Health \& Social Behavior 56(4), 534.

Hurst, W.; K. O’Brien (2002): China's Contentious Pensioners. China Quarterly 170, 345-360.

Jiao, K. (2010): The Relationship between Widowhood, Mortality and Retirement among Chinese Elderly. Population Research 34(3), 64-76. (In Chinese)

Jing, R.; A. Chou (2010): Workforce Participation among Older Adults in China: Current Knowledge and Future Research Directions. China Journal of Social Work 3(2-3), 247-258.

Kolev, A., A. Pascal (2002): What Keeps Pensioners at Work in Russia? Evidence from Household Panel Data. The Economics of Transition 10(1), 29-53.

Komp, K.; T. van Tilburg; M. Broese van Groenou (2010): Paid Work Between Age 60 and 70 years in Europé: A Matter of Socioeconomic Status? International Journal of Ageing and Later Life 5(1), 45-75.

Kovrova, I. (2007): Shaping a Pension System: Distributive and Incentive Effects of the Russian Pension Reforms. Ph.D. Dissertation, University of Turin. https://www.researchgate.net/publication/265148566_ Shaping_a_Pension_System_Distributive_and_Incentive_Effects_of_the_Russian_Pension_Reforms/ download.

Kozyreva, P.; M. Kosolapov; B. M. Popkin (2016): Data Resource Profile: The Russia Longitudinal Monitoring Survey-Phase II: Monitoring the Economic and Health Situation in Russia, 1994-2013. International Journal of Epidemiology 45(2), 395-401.

LaFave, D. (2016): Family Support and Elderly Well-being in China: Evidence from the China Health and Retirement Longitudinal Study. Ageing International 42, 142-158.

Lee, Y.-J.; Z. Xiao (1998): Children's Support for Elderly Parents in Urban and Rural China: Results from a National Survey. Journal of Cross-Cultural Gerontology 13(1), 39-62.

Levin, V. (2015): Promoting Active Aging in Russia: Working Longer and More Productive. Washington D.C.: The World Bank. http://documents.worldbank.org/curated/en/157901468190167727/pdf/99504-WPP143700-PUBLIC-Box393204B-Promoting-Active-Aging-in-Russia-final-cover.pdf. 
Li, H.; X. Shi; B. Wu (2016): The Retirement Consumption Puzzle Revisited: Evidence from the Mandatory Retirement Policy in China. Journal of Comparative Economics 44, 623-637.

Li, Y.; Xu, L.; Chi, U; Guo, P (2013): Participation in Productive Activities and Health Outcomes among Older Adults in Urban China. The Gerontologist 54(5), 784-796.

Ling, D. C.; I. Chi (2008): Determinants of Work among Older Adults in Urban China. Australasian Journal on Ageing 27, 126-133.

Liu, F. (2013): Research on Urban Old People Re-employment Problems in the Background of Aging Population in China. Ph.D. Thesis, Jilin University. (In Chinese).

Liu, T.; S. Li (2016): Pension Reform in China. Journal of Ageing \& Social Policy 28(1), 15-28.

Liu, H.; W. Q. Lou (2016): Patterns of Productive Activity Engagement among Older Adults in Urban China. European Journal of Ageing 13(4), 361-372.

Ma, X. (2018): Labor Market Segmentation by Industrial Sectors and Wage Gaps between Migrants and Local Labor Residents in Urban China. China Economic Review 47, 96-115.

Maestas, N.; J. Zissimopoulos (2010): How Longer Work Lives Ease the Crunch of Population Aging. Journal of Economic Perspectives 24(1), 139-160.

National Bureau of Statistics (2014): China Statistics Yearbook. Beijing, P.R. China. China Statistics Press.

Naughton, B. (2018): The Chinese Economy, Adaption and Growth, 2nd Edn. Cambridge, MA: MIT Press.

Niu, J. (2015): The Impact of Educational Attainment on Retirement Decision in China. Chinese Journal of Population Studies May, 58-67. (In Chinese)

Nolan, A.; A. Barrett (2019): Working Beyond age 65 in Ireland. Journal of Population Ageing 12, 299-326.

Platts, L. G.; K. Glaser (2017): Predictors of Returns to Work Following Retirement: A Prospective Analysis of Germany, Russia and the United Kingdom. https://osf.io/preprints/socarxiv/yvb82/.

Radl, J.; T. P. Gerber (2015): Work Beyond Pension Age in Russia: Labour Market Dynamics and Job Stability in a Turbulent Economy, in: Scherger, S. (ed.), Paid Work Beyond Pension Age. Houndmills: Palgrave Macmillan. 129-150.

Tecernina, N. V.; E. A. Techernin. (2002): Older People in Russia's Transitional Society: Multiple Deprivation and Coping Responses. Ageing and Society 22, 543-562.

Warendorf, M.; B. Akinwale; R. Landy; K. Matthews; D. Blane (2017): Who in Europe Works Beyond the State Pension Age and under which Conditions? Results from SHARE. Population Ageing 10, 269-285.

World Bank. (2020): Life expectancy at birth. https://data.worldbank.org/indicator/SP.DYN.LE00.FE.IN?locations. Accessed 3 August 2020.

World Bank. (2021): Unemployment, total (\% of total labor force) (modeled ILO estimate). https://data.worldbank.org/indicator/SL.UEM.TOTL.ZS.

Wu, L. (2013): Inequality of Pension Arrangements among Different Segments of the Labor Force in China. Journal of Ageing and Social Policy 25(2), 181-196.

Wu, X.; D. Treiman (2004): The Household Registration System and Social Stratification in China: 1955-1996. Demography 41, 363-384.

Yu, G.; G. Schömann (2015): Working Pensioners in China: Financial Necessity or Luxury of Choice? in: Scherger, S. (ed.). Paid Work Beyond Pension Age. Pelgrave Macmillan. Houndmills, Basingstoke, Hampshire, RG21 GXS, p 151-173.

Zhang, Z.; X. Wu (2017): Occupational Segregation and Earnings Inequality: Rural Migrants and Local Workers in Urban China. Social Science Research 61, 57-74. 


\section{Appendix: Literature Review on the Determinants of Working Among Older People in Urban China and Urban Russia}

In this section, we address the question of why some people work for earnings after reaching the normal retirement age in urban China and urban Russia based on earlier research. We will first discuss the studies on urban China that are related to our research question. ${ }^{17}$ Ling and Chi (2008) used data from the 2000 National Survey of the Aged Population in China and estimated labor force participation equations for seniors by gender. In addition to ill health and older age, the probability of working was negatively related to, for example, savings, the amount of durable goods owned, and the receipt of a public pension, and positively related to minority ethnicity status. Gilles et al. (2012, in a study that covers Indonesia and Korea) used information from the 2008 CHARLS to study urban and rural elderly persons by gender. Not many significant coefficients are reported for urban China, possibly due to comparatively small sample sizes. In contrast, one of the more recent studies estimating participation equations for urban China is Yu and Schömann (2015), who used the CHARLS 2011-12 and report several significant relationships: older age, female gender, and ill health were negatively associated with labor force participation, and being self-employed before reaching the normal retirement age was positively associated with participation. Each of these factors was significantly related to the probability of working among seniors. In contrast, a relationship between education and probability of working as a senior could not be established.

Niu (2015), using the CHARLS data from 2011, found that the relationship between education and work after the normal retirement age is not linear, as the regression coefficients on "junior school or below" and "senior school or technical school" were similar, whereas the probability of working among those in the category "college or above" was much higher than among that for those in the other groups. This study also found that the probability of working after the normal retirement age is higher for those who are self-employed or who work in the informal sector. Based on the CHARLS data from 1988 to 2005, Jiao (2010) studied the consequences of spousal death by estimating a Cox proportional hazard model. The results indicated that the death of a spouse is a statistically significant positive predictor of the surviving spouse exiting employment and of her or his death. This is attributable to psychological and health reasons. Liu and Lou (2016), who used the CHARLS 2011, report that no more than $10 \%$ urban adults $>60$ years worked for pay, a percentage identical to that for urban adults $>60$ years who were reported to be caring for grandchildren. ${ }^{18}$

We now turn to studies on Russia that are related to our research question. One relatively early study is Kolev and Pascal (2002), who raised research questions similar to ours and used the same database, the RLMS. However, their study refers to the situation in 1994-1999; thus, their period under study ends a few years before our period of study starts. The probability of holding a job and the number of hours worked were modeled in separate equations and estimated by gender. The results indicate that age, education, and health status matter for

17 Some studies have contrasted urban and rural seniors in China. Jing and Chou (2010) surveyed the literature in Chinese and English on participation in the labor market, emphasizing differences between urban and rural regions of China.

18 In Li et al. (2013) the assumed chain of causality is the opposite of that in the studies surveyed in the main body of this text. Using cross-sectional data collected in 2006, health status is related to labor force status and some other variables. This study reports that depressive symptoms are negatively related to being employed among males, but not among females. 
employment. The authors also demonstrate that there prevails a low sensitivity of pensioner employment to pension arrears and the amount of pension benefits.

Gerber and Radl (2014) used a number of surveys from Russia, covering the period 1991-2007, to analyze the labor market participation and earnings of Russian seniors. They confirmed the finding by Kolev and Pascal (2002) that economic need had pushed some pensioners to remain in the labor force, while more educated pensioners had greater opportunities to work. The authors summarize their findings by stating: "Elderly Russian are not disproportionally blocked from employment following market reform. Following the initial transition shock, the labor market activity increased." In Radl and Gerber (2015), the authors followed up the abovementioned study by analyzing data from the RLMS. Using the panel property of the data, the labor market status of workers before and after reaching the normal retirement age was described. For example, 7 out of 10 full-time employed persons remained in full-time employment when they reached the normal pension age.

Levin (2015) also reported results from the 2002 wave of the RLMS, the first of the 3 years we analyze in this article. In one analysis, the characteristics of persons who are working were contrasted with the characteristics of those who are not. In another analysis, the exit into retirement of men over age 50 and women over age 45 using the 2009 to 2012 waves of the RLMS was studied using a random-effects probit model. Among the results, it is worth mentioning that, in addition to health and education being positively related to working for pay, the probability of working for pay is also positively related to the individual's partner working for pay but is negatively related to household income. The same study also reported results from focus-group interviews with workers as well as employers. These interviews indicated that workers are pessimistic about their chances of finding a suitable job post-retirement, believing that the only options are unskilled, routine, and physically demanding low-paid jobs. Age is not generally explicitly considered as a discriminatory factor by employers. However, employers are hesitant to hire older job seekers because of their expected lower capacity for learning and adjusting to new approaches and teams.

Finally, we mention Platts and Glaser (2017), who studied the return-to-employment following retirement (that started before, at, or after the normal retirement age) in Germany, Russia, and the United Kingdom, estimating hazard rate models. For Russia, the authors analyzed the RLMS data from 1994 to 2012; for Germany, the German Socio-Economic Panel; and for the United Kingdom, the British Household Panel Survey. The results indicated that after a period of retirement, $17 \%$ of German retirees had worked for at least 1 year ("unretired"), whereas the corresponding proportion in Britain was $26 \%$, whereas in Russia it was as high as $42 \%$. Thus, compared with the situation in two prosperous market economies, the proportion of pensioners who work in Russia is high. In this study, not many characteristics of retired persons were found to predict unretirement. The clearest example is that reporting a good health status was positively related to the hazard of working after retirement. 